Estudios de Administración, vol. 8, NE 2, 2001

\title{
The Announcement Effect of Junk Bond Issues: an Analysis of the 1976-1989 Period
}

\author{
Augusto Castillo R. \\ Pontificia Universidad Católica de Chile
}

\begin{abstract}
This paper analyzes the impact of corporate junk bond offering announcements on stock prices for a sample of 680 issues of below investment grade bonds, during the 1976-1989 period. The sample shows a $-1.0 \%$ cumulative abnormal return (CAR) for a two day event window period, and the zero CAR hypothesis is rejected with $99 \%$ confidence. The cumulative abnormal returns are negative and significant for combined announcements of bond and equity issues (CAR of $-2.10 \%$ ), and for announcements of convertible bond issues (CAR of $-1.24 \%$ ). Announcements of issues of straight bonds (CAR of $-0.24 \%$ ) are not significantly different from zero. Differences in CARs are observed across subsamples formed on the basis of size of the issuer, relative size of the issue, rating of the issue, name of the underwriter, market value of the issuer, and year of issue, but these variables are not significant when used in cross sectional regressions. The only variables with some explanatory power in those regressions are the ones indicating type of the issue, recession periods, and the dummy used to identify announcements made in 1976 (the first year junk bond issues were allowed).
\end{abstract}

I would like to thank Amit Goyal, Michael Brennan, Javier Gómez B., Gustavo Maturana, Eduardo Schwartz and an anonymous referee for valuable comments on previous versions of this paper

Extracto 
En este artículo se analiza el impacto del anuncio de emisión de bonos corporativos de baja calidad (o bonos basura) en el precio accionario para una muestra de 680 emisiones ocurridas en Estados Unidos durante el período 1976-1989. La muestra presenta un retorno anormal acumulado (RAA) de $-1.0 \%$ para una ventana de evento de dos días, y la hipótesis de cero retorno anormal acumulado es rechazada con un $99 \%$ de confianza. Los retornos anormales acumulados son negativos y significativos para anuncios combinados de emisión de bonos y patrimonio (RAA de $-2.1 \%$ ), y para los anuncios de de emisiones de bonos convertibles (RAA de $1.24 \%$ ). Anuncios de emisiones de bonos regulares (RAA de $0.24 \%$ ) no son significativamente distintos de cero. Diferencias en RAA son observadas en submuestras formadas en base a diferencias de tamaño del emisor, tamaño relativo de la emisión, rating de la emisión, nombre del underwriter, valor de mercado del emisor, y año del anuncio de la emisión, pero estas diferencias no son significativas cuando se incorporan como variables explicatorias en regresiones de corte transversal. Las únicas variables con algún poder explicatorio en esas regresiones son aquellas que indican el tipo de emisión, la existencia de períodos recesivos, y la dummy utilizada para identificar el primer año en que estas emisiones de bonos basura fueron hechas.

Until the late 1970s new or financially troubled companies in the U.S. market were forced to finance their operations and investments with internal resources or the issue of new equity. This was because banks were generally unwilling to lend to such companies ${ }^{1}$, and because the issue of bonds was basically reserved to companies that were able to offer investment grade debt. $^{2}$ And suddenly something changed. A group of underwriters, led by Michael Milken from Drexel Burnham, was able to convince investors of

${ }^{1}$ Actually banks would lend to companies, subject to some conditions in terms of size and age of the company, but the credits offered would be short term in nature and would usually include many restrictive covenants. See (Gilson and Warner, 1999) for a discussion on this.

${ }^{2}$ When a firm issues bonds, they are rated by the Moody's Investor Service or by the Standard and Poor Company. The bonds that are perceived to offer low default risk, are denominated investment grade bonds, and those that offer a high default risk, are known as junk bonds. Standard and Poor's rating goes from AAA for the less risky bonds to D to the more risky ones. An issue is denominated a junk bond if it is rated as $\mathrm{BB}+$ or lower than $\mathrm{BB}+$ by the S\&P Corporation. These bonds are also called high yield bonds and below investment grade bonds. Source: (S\&P Bond Guide, December 1989). 
the attractiveness of those bonds. The argument was simple: Most of the default risk of those junk bonds could be diversified if held in a portfolio, and they offered a very attractive expected return ${ }^{3}$.

Even though junk bonds represented less than $2 \%$ of the total corporate debt offerings in the early 1970s, they gained importance rapidly in the following years to become more than $20 \%$ of the total of corporate bond offerings by the late 1980s. As a result the high yield bond market became the fastest growing, and one of the largest segments of the fixed income markets.

This positive trend was broken by the end of the 1980s for several reasons. Major market participants were charged with serious Securities and Exchange Commission (SEC) violations, such as insider trading. As a result of those charges, arbitrageur Ivan Boesky, Dennis Levine, and Martin Siegel of Drexel Burnham were convicted between 1986 and 1987. By 1989 Michael Milken had to resign from Drexel Burnham and one year later he would receive a ten year prison sentence, and Drexel Burnham would have to file for bankruptcy. The market crash of October 1987, and the default of some junk bond issuers in the late 1980s forced some savings and loan (S\&L) companies that had overinvested in junk bonds to file for bankruptcy. The Congress reacted with new regulations in 1989 that forced all S\&Ls to liquidate their investments in the high yield bonds.

There have been many studies of the effect of corporate debt offering announcements on equity prices, and a few studies of the long run ex-post performance of the junk bond issues. But there have been no studies of the effect of the issue of junk bonds on the equity of the issuers.

What effect should we expect the announcement of a bond issue to have on equity prices? There is no single answer to this question since different authors have developed competing theories. Following (Eckbo, 1986), we can group those theories in three: (i) the zero impact hypotheses proposed by (Modigliani and Miller, 1958), and by (Miller, 1977) basically state that the leverage ratio has no effect on the firm's market value. This implies that the announcement of a bond issue should generate no abnormal return; (ii) the positive impact hypotheses, proposed among others by

${ }^{3}$ The argument, though used by Michael Milken, was the result of a study performed by W.B. Hickman, and published in 1958. (Hickman, 1958). 
(Modigliani and Miller, 1963), (Kraus and Litzenberger, 1973), (Brennan and Schwartz, 1978), (DeAngelo and Masulis, 1980), (Myers, 1977), (Jensen and Meckling, 1976), (Galai and Masulis, 1976), (Leland and Pyle, 1977), and (Heinkel, 1982), state that debt has a positive impact in a firm's market value ${ }^{4}$. This means that the announcement of a bond issue should generate a positive abnormal return; finally we have the (iii) negative impact hypotheses, proposed among others by (Miller and Rock, 1985), (Myers and Majluf, 1984), and (Covitz and Harrison, 1999) ${ }^{5}$. From the negative impact theories we conclude that the announcement of a debt issue should have a negative impact on a firm's market value.

Empirical evidence generally shows that the announcement of equity and convertible debt issues results in stock price decreases, while the announcement of straight debt issues generates either stock price increases or no significant impact on stock prices. The evidence found by (Asquith and Mullins, 1986), (Dann and Mikkelson, 1984), (Eckbo, 1986), (Linn and Pinegar, 1988), (Masulis and Korwar, 1986), (Mikkelson and Partch, 1986), (Schipper and Smith, 1986), (Szewczyk, 1992), (Jain, 1992), (Manuel, Brooks, and Schadler, 1993), and (Shyam-Sunder, 1991) among others, can be summarized as follows:

- The announcement of equity issues generates more negative abnormal

${ }^{4}$ (Modigliani and Miller, 1963) assume that there is a tax shield generated by debt that makes the value of the company to increase with the proportion of debt over assets. (Kraus and Litzenberger, 1973), (Brennan and Schwartz, 1978), and (De Angelo and Masulis, 1980) assume there is a trade off between a tax advantage of debt and a cost of financial distress. (Myers, 1977) assumes a trade off between a tax advantage of debt and agency costs and adverse managerial effects of debt. (Jensen and Meckling, 1976) assume a tradeoff between agency costs of debt and agency costs of equity. Finally both (Leland and Pyle, 1977) and (Heinkel, 1982) present models with information asymmetries where managers posses superior information relative to investors.

5 (Miller and Rock, 1985) present an asymmetric information model where a larger than expected external financing reveals a lower than expected generated cash flow. (Myers and Majluf, 1984) present an asymmetric information model where facing an issue of stocks or bonds the uninformed investors will ask for a discount to hedge against the risk of buying an overvalued security. (Covitz and Harrison, 1999) develop and test a recursive model of debt issuance and rating migration, where rating agencies reveal information over time. This adverse selection model assumes that firms possess private information and use it to time their bond issuance. As a result, debt issuance provides a negative signal of debt rating migration. They also predict that the signal strengthens with economic downturns. 
returns than the announcement of any other kind of securities.

- Abnormal returns associated with the announcement of issues of convertible debt are also negative and significant.

- Abnormal returns associated with the announcement of issues of straight debt are either positive or not significantly different from zero.

In all these studies the samples are mainly composed by issues of investment grade bonds, with junk bonds representing no more than $15 \%$ of the total issues considered. The issue of junk bonds may appear to be different from other issues of debt for at least two reasons: First, companies that issue junk bonds may not have easy access to other sources of funding, so that the appearance of this funding alternative may generate an unanticipated value improvement by allowing firms with positive NPV projects to undertake them. This argument would suggest a positive abnormal return of equity on the announcement of the issue.

The second reason is that the announcement of the bond's issue would come with the confirmation of the low rating given by experts on the companies' new debt and this could be actually bad news for the equity holders if they were not sure about how troubled the company really was. These two arguments could explain a difference in the impact of the announcement of a junk bond issue.

Three studies provide empirical evidence about the association between bond rating and the stock price reaction to bond issues. (Mikkelson and Partch, 1986), (Eckbo, 1986), and (Shyam-Sunder, 1991) all conclude that there is no statistically significant difference in stock price reactions to debt issues across rating classes ${ }^{6}$.

In this paper I examine the impact of the announcement of issues of junk bonds on the stock prices of the issuing firms for 680 issues made between 1976 and 1989. I will give particular attention to the issues of bonds underwritten by Drexel Burnham because of the important role of this company in developing the market and the subsequent criminal prosecution faced by some of its senior executives. Drexel Burnham filed for bankruptcy in 1990, and this is one reason for not considering issues after 1989. The

\footnotetext{
${ }^{6}$ The samples included only a small number of junk bond issues in these three
} cases. 
other reason is that this paper is a chapter of a longer study where long term post issue stock performance of junk bond issuers are also measured. The rest of this paper is organized as follows. Section 1 presents an outline of the methodology applied to perform the event study. The empirical results are shown in section 2, while section 3 concludes the paper.

\section{Methodology.}

\section{A. Event Definition and Sample Design:}

The event to be studied is the announcement of the issue of junk bonds made by companies in the U.S. between 1976 and 1989. The period was chosen to include the fast growing period of the market, when Drexel Burnham was one of the main players. A total of 680 junk bond issues were selected to be considered in the sample, using the following procedure:

(1) A list of all the issues of corporate debt ranked $\mathrm{BB}+$ or lower as indicated in the Standard and Poor's Monthly Bond Guides was generated. A total of 1260 issues during the 1976-1989 period were identified.

(2) The Wall Street Journal Index (WSJI) was used to identify the exact announcement date of each issue, and other details such as the type of debt issued, the amount of the issue, the rating given to the issue, and the name of the underwriter. A total of 183 issues whose announcement dates were not found were excluded from the sample.

(3) Issues were excluded from the sample if the name of the issuer was not found in CRSP, or if not enough returns were available during the corresponding estimation period and event window ${ }^{7}$. No overlapping of estimation periods or event windows for two issues of the same company were allowed either, to avoid the bias that having issues of bonds over estimation periods could generate. When overlap occurred

\footnotetext{
${ }^{7}$ The estimation window plus the event window required a total of 201 daily returns, and a maximum of 5 missing returns was allowed for each company.
} 
among two or more issues of the same firm, only the first one was included in the sample. A total of 397 issues were excluded from the sample in this step.

The characteristics of the 680 issues in the sample are summarized in Tables 1,2 , and 3. Table 1 shows that the number of issues per year went from 9 in 1976 to 44 in 1989, with a maximum of 86 issues in 1986. The total amount of debt issued per year grew most of the time during the period, but showed a declining tendency starting on $1987^{8}$, probably due to the combined effect of the SEC violation charges presented against major junk bond market participants, the October 1987 stock market crash, the default of several junk bond issuers, and the new regulations imposed over the S\&L industry. Table 1 also shows that the issues in the sample represent $45 \%$ of the total number of issues of junk bonds over the same period.

Table 2 shows the annual offerings classified by underwriter ${ }^{9}$ and by type of security issue. Out of the $670^{10}$ issues considered here, 271 (or $40 \%$ of them) were straight debt issues, 312 (or $47 \%$ of them) were convertible debt issues, and 87 (or 13\% of them) corresponded to simultaneous issues of debt and equity. The mix of Drexel Burnham offerings differed from that of the other underwriters: while for Drexel Burnham $53 \%$ of the issues were straight debt, $31 \%$ of the issues were convertible bonds, and $15 \%$ of the issues were combined issues of debt and equity, the corresponding proportions were $35 \%, 53 \%$, and $12 \%$ for the other underwriters. Thus Drexel issued a significantly higher proportion of straight debt issues and a significantly lower proportion of convertibles, compared to the proportions issued by the other underwriters. As shown in Table 2, these proportions changed also through time.

\section{Table 1}

Annual Distribution of Junk Bond Offerings in the Sample, from 1976 to $1989^{a}$

\footnotetext{
${ }^{8}$ In 1981 the growing tendency is also broken. While the number of issues in 1980 was abnormally high, many of those issues were small in amount, so that the total annual amount issued was very similar to that in 1979 and 1981.

${ }^{9}$ We distinguish between Drexel Burnham and all other underwriters.

${ }^{10}$ Out of the 680 issues considered in the sample ten of them were excluded in the analysis of Table 2 because in those cases the firms issued more than one type of debt at the same time.
} 


\begin{tabular}{|c|c|c|c|c|}
\hline YEAR & NUMBER OF ISSUES & TOtAL DEBT Issued $^{\mathrm{B}}$ & AvERAGE SIZE OF ISSUE $^{\mathrm{B}}$ & SAMPLE/ TOTAL JB ${ }^{\mathrm{C}}$ \\
\hline 1976 & 9 & 282,0 & 31,3 & 0,53 \\
\hline 1977 & 28 & 765,0 & 27,3 & 0,65 \\
\hline 1978 & 39 & 1010,8 & 25,9 & 0,69 \\
\hline 1979 & 41 & 1320,0 & 32,2 & 0,97 \\
\hline 1980 & 79 & 1310,0 & 16,6 & 0,99 \\
\hline 1981 & 23 & 1060,0 & 46,1 & 0,90 \\
\hline 1982 & 36 & 2534,0 & 70,4 & 0,96 \\
\hline 1983 & 60 & 4194,0 & 69,9 & 0,61 \\
\hline 1984 & 58 & 5407,0 & 93,2 & 0,41 \\
\hline 1985 & 67 & 5121,0 & 76,4 & 0,53 \\
\hline 1986 & 86 & 11748,0 & 136,6 & 0,36 \\
\hline 1987 & 69 & 11845,0 & 171,7 & 0,43 \\
\hline 1988 & 41 & 8556,0 & 208,7 & 0,32 \\
\hline 1989 & 44 & 6001,0 & 136,4 & 0,40 \\
\hline 1976-1989 & 680 & 61153,8 & 89,9 & 0,45 \\
\hline
\end{tabular}

${ }^{a}$ If a company announced the intention to issue more than one kind of security on the same day, that was counted as one issue.

${ }^{\mathrm{b}}$ In US\$ millions.

${ }^{\mathrm{c}}$ This is the proportion of junk bond issues in the sample over total junk bond issues, both in US\$. The total amount of junk bond issues in US\$ was obtained from monthly issues of the S\&P Bond Guide. 
Table 2

Annual Distribution of Junk Bond Offering in the Sample, Classified by Underwriter and Nature of the Issue

\begin{tabular}{|c|c|c|c|c|c|c|c|c|c|}
\hline \multirow{3}{*}{ YEAR } & \multicolumn{3}{|c|}{$\begin{array}{c}\text { TOTAL } \\
\text { SAMPLE }\end{array}$} & \multicolumn{3}{|c|}{$\begin{array}{c}\text { DREXEL } \\
\text { BURNHAM }\end{array}$} & \multicolumn{3}{|c|}{$\begin{array}{c}\text { OTHER } \\
\text { UNDERWRITERS }\end{array}$} \\
\hline & $\begin{array}{l}\text { STRAIGHT } \\
\text { ST }\end{array}$ & CONVERTIB & $\overline{\text { DEBT AND }}$ & $\overline{\text { STRAIGHT }}$ & CONVERTIB & $\overline{\text { LE DEBT AND }}$ & STRAIGHT & CONVERTIBLE & $\overline{\text { DEBT AND }}$ \\
\hline & DEBT & DEBT & EQUITY & DEBT & DEBT & EQUITY & DEBT & DEBT & EQUITY \\
\hline 1976 & 4 & 4 & 1 & 0 & 0 & 0 & 4 & 4 & 1 \\
\hline 1977 & 11 & 8 & 9 & 5 & 0 & 1 & 6 & 8 & 8 \\
\hline 1978 & 20 & 10 & 9 & 6 & 2 & 3 & 14 & 8 & 6 \\
\hline 1979 & 23 & 10 & 7 & 6 & 0 & 1 & 17 & 10 & 6 \\
\hline 1980 & 25 & 49 & 5 & 5 & 3 & 3 & 20 & 46 & 2 \\
\hline 1981 & 7 & 15 & 1 & 4 & 3 & 1 & 3 & 12 & 0 \\
\hline 1982 & 16 & 19 & 1 & 8 & 4 & 0 & 8 & 15 & 1 \\
\hline 1983 & 20 & 24 & 15 & 13 & 6 & 9 & 7 & 18 & 6 \\
\hline 1984 & 25 & 20 & 12 & 12 & 10 & 3 & 13 & 10 & 9 \\
\hline 1985 & 18 & 35 & 14 & 8 & 10 & 4 & 10 & 25 & 10 \\
\hline 1986 & 29 & 47 & 7 & 12 & 14 & 2 & 17 & 33 & 5 \\
\hline 1987 & 30 & 32 & 4 & 16 & 4 & 2 & 14 & 28 & 2 \\
\hline 1988 & 25 & 13 & 2 & 7 & 6 & 2 & 18 & 7 & 0 \\
\hline 1989 & 18 & 26 & 0 & 5 & 1 & 0 & 13 & 25 & 0 \\
\hline \multicolumn{10}{|l|}{$1976 / 198$} \\
\hline 9 & 271 & 312 & 87 & 107 & 63 & 31 & 164 & 249 & 56 \\
\hline
\end{tabular}

The 10 cases where a company announced the issue of straight and convertible debt in the same day were excluded here. 
Table 3 shows annual offerings classified by underwriter and by initial rating. Out of the $676^{11}$ issues considered here, 180 (27\%) were rated BB, $431(64 \%)$ were rated B, and $65(9 \%)$ were rated CCC. For Drexel the corresponding proportions are $21 \%$ of $\mathrm{BB}, 69 \%$ of $\mathrm{B}$, and $10 \%$ of CCC. For other underwriters the proportions are $29 \%$ of $\mathrm{BB}, 62 \%$ of $\mathrm{B}$, and $9 \%$ of CCC. Thus the proportions of issues by rating are very similar between Drexel and the other underwriters. As shown by Table 3, these proportions change also through time. For Drexel Burnham the proportion of B rated issues decreases while the proportion of $\mathrm{CCC}$ rated bonds increases through time. For other underwriters the proportion of $\mathrm{B}$ rated issues increases while the proportion of $\mathrm{CCC}$ rated bonds decreases through time.

\section{B. Measuring Abnormal Returns.}

The effect of the announcement can be estimated as the deviation of the return of each security from its normal return on the dates around the event. For each company $i$ and period $t$ we have

$$
\varepsilon_{i t}=R_{i t}-E\left[R_{i t} \mid X_{t}\right]
$$

where $\varepsilon_{i t}$ is the abnormal return of company $\mathrm{i}$ in period $\mathrm{t}, R_{i t}$ is the return of that firm in that period, $\mathrm{E}\left[R_{i t} \mid \mathrm{X}_{\mathrm{t}}\right]$ is the normal or expected return for company $\mathrm{i}$ in period $\mathrm{t}$, and $\mathrm{X}_{\mathrm{t}}$ corresponds to the conditioning information for the model of normal performance.

The normal return can be modeled in different ways. Two of the most commonly used models are (i) the Constant Mean Return Model, where $X_{t}$ corresponds to the average return of the security over the estimation window, and (ii) the Market Model, where $\mathrm{X}_{\mathrm{t}}$ corresponds to the return of the market portfolio in period $t$, and a stable linear relationship is assumed to exist between the market portfolio return and the return of the security.

\footnotetext{
${ }^{11}$ Out of the 680 issues considered in the sample four of them were excluded in the analysis of Table 3 because in those cases the firms issued more than one type of debt at the same time.
} 
Table 3

Annual Distribution of Junk Offerings in the Sample, Classified by Underwiter and Initial Rating

\begin{tabular}{cccccccccc}
\hline & \multicolumn{3}{c}{ TOTAL SAMPLE } & \multicolumn{3}{c}{ DREXEL BURNHAM } & \multicolumn{3}{c}{ OTHERUUNDERWRITERS } \\
YEAR & \multicolumn{2}{c}{ RATING AsSIGNED BY S\&P } & \multicolumn{2}{c}{ RATING AsSIGNED BY S\&P } & \multicolumn{3}{c}{ RATING ASSIGNED BY S\&P } \\
& BB & B & CCC & BB & B & CCC & BB & B & CCC \\
\hline 1976 & 7 & 2 & 0 & 0 & 0 & 0 & 7 & 2 & 0 \\
1977 & 11 & 13 & 4 & 3 & 3 & 0 & 8 & 10 & 4 \\
1978 & 8 & 28 & 3 & 1 & 10 & 0 & 7 & 18 & 3 \\
1979 & 6 & 31 & 4 & 1 & 6 & 0 & 5 & 25 & 4 \\
1980 & 26 & 51 & 2 & 0 & 11 & 0 & 26 & 40 & 2 \\
1981 & 7 & 16 & 0 & 3 & 5 & 0 & 4 & 11 & 0 \\
1982 & 15 & 19 & 2 & 7 & 5 & 0 & 8 & 14 & 2 \\
1983 & 13 & 41 & 6 & 5 & 22 & 2 & 8 & 19 & 4 \\
1984 & 15 & 38 & 4 & 7 & 16 & 3 & 8 & 22 & 1 \\
1985 & 18 & 44 & 5 & 6 & 13 & 3 & 12 & 31 & 2 \\
1986 & 17 & 52 & 15 & 2 & 23 & 4 & 15 & 29 & 11 \\
1987 & 19 & 40 & 10 & 6 & 13 & 5 & 13 & 26 & 5 \\
1988 & 8 & 28 & 4 & 2 & 10 & 4 & 6 & 19 & 0 \\
1989 & 10 & 28 & 6 & 1 & 5 & 0 & 9 & 23 & 6 \\
$976 / 198$ & 180 & 431 & 65 & 44 & 142 & 21 & 136 & 289 & 44 \\
\hline
\end{tabular}

The 4 cases where the same company made two or more issues with different rating on the same day were excluded here. 
The Constant Mean Return Model is represented by

$$
\begin{aligned}
& R_{i t}=\mu_{i}+\varepsilon_{i t} \\
& E\left[\varepsilon_{i t}\right]=0 \quad \operatorname{Var}\left[\varepsilon_{i t}\right]=\sigma_{e i}^{2}
\end{aligned}
$$

where $\mu_{i}$ corresponds to the mean return of security $\mathrm{i}$, and $\varepsilon_{i t}$ represents the deviation from the mean for security $\mathrm{i}$ in period t. As (Brown and Warner, 1985) show, this is probably the simplest model for normal returns, but it usually gives results that are very similar to the ones generated by more sophisticated models over short time intervals.

The Market Model has the following linear specification

$$
\begin{aligned}
& R_{i t}=\alpha_{i}+\beta_{i} R_{m t}+\varepsilon_{i t} \\
& E\left[\varepsilon_{i t}\right]=0 \quad \operatorname{Var}\left[\varepsilon_{i t}\right]=\sigma_{e i}^{2}
\end{aligned}
$$

where $R_{i t}$ and $R_{m t}$ are the the return on period $t$ of security $i$ and the return of the market portfolio on that same period, and $\varepsilon_{i t}$ corresponds to the disturbance term. The parameters of the Market Model are $\alpha_{i}, \beta_{i}, a n d \sigma_{e i}^{2}$. The Market Model removes the portion of the returns that are related to the movements of the market. This reduces the variance of abnormal returns, and therefore increases the ability of the model to detect event effects, relative to the Constant Mean Return Model.

The normal return has also been modeled using more constrained models such as the Capital Asset Pricing Model (CAPM) ${ }^{12}$ and the Arbitrage Pricing Theory model (APT) ${ }^{13}$. The CAPM was extensively used in the 1970 's, but the validity of both this model and of the restrictions we need to impose are not universally accepted today. On the other hand a properly chosen APT model does not impose false restrictions on mean returns, but complicates the implementation of an event study and does not offer much advantage relative to the unrestricted market model.

Brown and Warner, (1980) compare the different methodologies used in event studies to measure security price performance, and conclude that beyond a simple one factor market model, there is no evidence that

${ }^{12}$ ((Sharpe, 1964) and (Lintner, 1965) developed the CAPM.

${ }^{13}$ (Ross, 1976) developed the APT. 
more complicated methodologies convey any benefit. In fact they conclude that those more sophisticated methodologies can make the researcher worse off $^{14}$. (Brown and Warner, 1985) confirm the conclusions using daily instead of monthly returns.

Considering the arguments given above, in this paper I assume that the Market Model properly describes the normal return of securities. I also assume here that the CRSP value-weighted index is a reasonable proxy for the market portfolio. Even though they are not reported here, very similar results were obtained when using the S\&P500 index as the market portfolio.

\section{Estimation of the Market Model Parameters and Computation of Abnormal Returns ${ }^{15}$.}

Some notation must be defined here. Let $\mathrm{t}=0$ be the event date, $\mathrm{T}_{1}=-190$ (190 trading days before the event) to $T_{2}=-11$ (11 trading days before the event) be the estimation window, and $T_{2}+1=-10$ (10 trading days before the event) to $T_{3}=+10$ (10 trading days after the event) be the event window. Define $L_{21}=T_{2}-T_{1}$, and $L_{32}=T_{3}-T_{2}$ as the lengths of the estimation window and the event window respectively ${ }^{16}$. Figure 1 shows the estimation period and the event window schematically.

We start by estimating the Market Model parameters over the estimation period. The returns from the estimation window can be represented with the regression system

$$
R_{i}=\alpha_{i}+\beta_{i} R_{m}+\varepsilon_{i}
$$

where $R_{i}$ is the $\left(L_{21} \times 1\right)$ vector of company $i$ returns during the estimation window period, $\alpha_{i}$ represents a $\left(\mathrm{L}_{21} \times 1\right)$ vector composed by the intercept parameter $\alpha_{i}, \beta_{i}$ is the slope parameter for firm $\mathrm{i}$, and $\mathrm{R}_{\mathrm{m}}$ is a $\left(\mathrm{L}_{21} \times 1\right)$ vector of market return observations.

${ }^{14}$ (Brown and Warner, 1980) compare the mean adjusted return model, the market adjusted return model, the market model, the Fama-MacBeth model, and the control portfolio model.

${ }^{15}$ In this section I follow closely the event study methodology described by (Campbell, Lo, and Mackinlay, 1997).

${ }^{16}$ In this paper L21 = 180 trading days, and L32 = 21 trading days. 
Figure 1

The Estimation Period and the Event Window

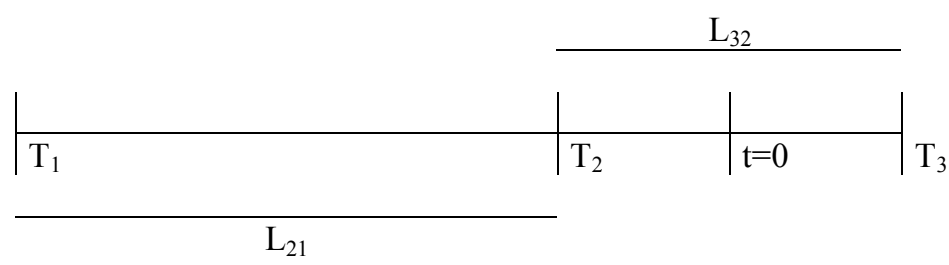

Time is measured relative to the event day. The event day is $\mathrm{t}=0$.

The estimation period starts on day $T_{1}=-190$ and ends on day $T_{2}=-11$, having a length of $\mathrm{L}_{21}=180$ days .

The event window starts on day $\mathrm{T}_{2}+1=-10$, and ends on day $\mathrm{T} 3=10$, having a length of $\mathrm{L}_{32}=21$ days.

The parameters are estimated by ordinary least squares (OLS) ${ }^{17}$. Using the OLS parameter estimates we can now compute the vector $\hat{\varepsilon}_{i}^{*}$ of abnormal returns over the event window as

$$
\hat{\varepsilon}_{i}^{*}=R_{i}^{*}-\hat{\alpha}_{i}-\hat{\beta}_{i} R_{m}^{*}
$$

where $R_{i}^{*}$ corresponds to a $\left(\mathrm{L}_{32} \times 1\right)$ vector of event window returns, $\hat{\alpha}_{i}$ and $\hat{\beta}_{i}$ represent the previously estimated parameters, and $R_{m}^{*}$ is a $\left(\mathrm{L}_{32} \times 1\right)$ vector of market return observations. Table 4 reports a summary of the $\hat{\alpha}_{i}$ and $\hat{\beta}_{i}$ parameter estimates for the firms in the sample, and their significance. The second part of Table 4 shows the $\hat{\beta}_{i}$ parameter estimates under a more restricted version of the market model that assumes $\alpha$ s are all zero. This more restricted version was the one selected to perform the

${ }^{17}$ (Brown and Warner, 1985) explored how potential problems such as (i) nonnormality of returns and excess returns, (ii) bias in OLS estimates of market model parameters in the presence of non-synchronous trading, (iii) autocorrelation in daily excess returns, and (iv) variance increases on the days around an event, affected the event study methodologies. They compared the OLS market model to other alternatives such as the Scholes-Williams and the Dimson methodologies. Their results reinforced the conclusion of previous work with monthly data: methodologies based on the OLS market model and using standard parametric tests are well specified under a variety of conditions, and alternative methodologies convey no clear-cut benefit in an event study. 
analysis of abnormal returns presented in the remaining of the paper ${ }^{18}$.

Table 4

Distribution of Market Model Parameter Estimates

\begin{tabular}{lrr} 
ESTIMATES & ALPHA & BETA \\
\hline Maximun & $1,08 \%$ & 3,62 \\
90 percentile & $0,37 \%$ & 1,74 \\
75 percentile & $0,23 \%$ & 1,26 \\
Median & $0,11 \%$ & 0,86 \\
25 percentile & $0,01 \%$ & 0,54 \\
10 percentile & $-0,11 \%$ & 0,29 \\
Minimum & $-0,49 \%$ & $-0,53$ \\
Mean & $0,13 \%$ & 0,94 \\
Average $t$ statistic & $0,64 \%$ & 4,31
\end{tabular}

Distribution of Parameter Estimates when Intercept is Zero

\begin{tabular}{lr} 
ESTIMATES & BETA \\
\hline Maximun & 4,34 \\
90 percentile & 1,80 \\
75 percentile & 1,26 \\
Median & 0,64 \\
25 percentile & 0,05 \\
10 percentile & $-0,52$ \\
Minimum & $.2,10$ \\
Mean & 0,64 \\
Average $t$ statistic & 4,31
\end{tabular}

\section{Aggregation of Abnormal Returns.}

${ }^{18}$ The firms issuing junk bonds during the 1976-1989 period presented significantly positive market-adjusted returns over the three years preceding the issues, and also presented significantly negative returns over the seven years period following the issues. This imposes an additional problem on the definition of an estimation period to compute the parameters required to measure abnormal returns around the issue announcement. To avoid any biases the abnormal returns were computed here using the traditional market model first, and then a more restricted version where the intercepts were assumed to be zero. The amount and significance of the abnormal returns computed using these two alternative methodologies were almost identical when a two days event window was used. 
In order to be able to draw inferences for the event, the abnormal returns must be aggregated both across securities and through time ${ }^{19}$. To aggregate across securities we define the $\left(L_{32} \times 1\right)$ vector of average abnormal returns $\mathrm{AR}$ as

$$
A R=\frac{1}{N} \sum_{i=1}^{N} \hat{\varepsilon}_{i}^{*}
$$

where $\mathrm{N}$ is the number of securities in the sample. The variance of $\mathrm{AR}$, under the assumption of no correlation of excess returns across securities, is computed as

$$
\operatorname{Var}[A R]=V=\frac{1}{N^{2}} \sum_{i=1}^{N} V_{i}
$$

where $\mathrm{V}_{\mathrm{i}}$ represents the conditional covariance matrix of $\hat{\varepsilon}_{i}^{*}$. We can now aggregate the average abnormal returns through time. Define $\operatorname{CAR}\left(\mathrm{t}_{1}, \mathrm{t}_{2}\right)$ as the cumulative average abnormal return from $t_{1}$ to $t_{2}$, where $T_{2}+1 \leq t_{1} \leq t_{2} \leq T_{3}$. Then we have

$$
C A R\left(t_{1}, t_{2}\right)=\gamma^{\prime} A R
$$

where $\mathrm{CAR}\left(\mathrm{t}_{1}, \mathrm{t}_{2}\right)$ would follow a normal distribution process with mean zero and variance given by

$$
\operatorname{Var}\left[C A R\left(t_{1}, t_{2}\right)\right]=\bar{\sigma}^{2}\left(t_{1}, t_{2}\right)=\gamma^{\prime} V \gamma
$$

${ }^{19}$ The aggregation presented here assumes that there is no overlapping in the event windows of the included securities. This would result in independent abnormal returns and cumulative abnormal returns across securities. We will correct for clustering in section 2.2.1. 
In both (8) and (9), $\gamma$ represents a $\left(L_{32} \times 1\right)$ vector with ones in positions $t_{1}$ $\mathrm{T}_{2}$ to $\mathrm{t}_{2}-\mathrm{T}_{2}$ and zeros elsewhere. We can now test the null hypothesis of zero cumulative abnormal returns using $\mathrm{t}_{\mathrm{CAR}}$ where

$$
t_{C A R}\left(t_{1}, t_{2}\right)=\frac{C A R\left(t_{1}, t_{2}\right)}{\bar{\sigma}^{2}\left(t_{1}, t_{2}\right)^{1 / 2}} \sim N(0,1)
$$

\section{Empirical Results}

\section{A. Analysis of Average Abnormal Returns.}

Table 5 and Figure 2 summarize the effect of the junk bond issue announcements on the stock market prices of the issuers. On average the firms in the sample experienced an abnormal return of $-1.0 \%$ ( $\mathrm{t}$ statistic of 6.21 )over the 2 day period (day -1 to day 0 ). The abnormal returns for the other intervals in the event window are positive but not that significant. Over the 21 day event window period the sample experienced an abnormal return of $0.43 \%$ (t statistic of 0.86 ).

Figure 3 shows the cumulative abnormal return for the 2 day period

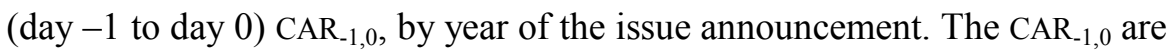
negative in all but one year (1981), but different in value through time, with particularly high negative abnormal returns on years 1976 and 1977. In section 2.3 I will explore how the composition of the announcements in terms of size of the issuer, relative size of the issue, name of the underwriter, rating of the issue, pre announcement performance, economic activity, and type of issue could explain the differences observed here. 
Table 5

Abnormal Returns Around the Bond Issue Announcements

\begin{tabular}{|c|c|c|c|c|c|}
\hline DAY & AR $(\%)$ & $t$ STATISTIC & & CAR $(\%)$ & $t$ STATISTIC \\
\hline-10 & $0,21 \%$ & 1,94 & & $0,21 \%$ & 1,94 \\
\hline-9 & $0,09 \%$ & 0,78 & & $0,30 \%$ & 1,93 \\
\hline-8 & $0,12 \%$ & 1,13 & & $0,42 \%$ & 2,23 \\
\hline-7 & $0,11 \%$ & 0,97 & & $0,53 \%$ & 2,41 \\
\hline-6 & $0,12 \%$ & 1,12 & & $0,65 \%$ & 2,56 \\
\hline-5 & $0,02 \%$ & 0,14 & & $0,67 \%$ & 2,48 \\
\hline-4 & $0,04 \%$ & 0,37 & & $0,71 \%$ & 2,44 \\
\hline-3 & $-0,12 \%$ & $-1,07$ & & $0,59 \%$ & 1,90 \\
\hline-2 & $0,15 \%$ & 1,40 & & $0,75 \%$ & 2,26 \\
\hline-1 & $-0,56 \%$ & $-5,06$ & $* *$ & $0,19 \%$ & 0,55 \\
\hline 0 & $-0,41 \%$ & $-3,71$ & $* *$ & $-0,22 \%$ & $-0,60$ \\
\hline 1 & $-0,01 \%$ & $-0,07$ & & $-0,23 \%$ & $-0,59$ \\
\hline 2 & $0,08 \%$ & 0,71 & & $-0,15 \%$ & $-0,37$ \\
\hline 3 & $0,05 \%$ & 0,46 & & $-0,10 \%$ & $-0,24$ \\
\hline 4 & $-0,01 \%$ & $-0,07$ & & $-0,10 \%$ & $-0,24$ \\
\hline 5 & $0,17 \%$ & 1,52 & & $0,06 \%$ & 0,14 \\
\hline 6 & $0,03 \%$ & 0,30 & & $0,10 \%$ & 0,21 \\
\hline 7 & $0,27 \%$ & 2,42 & $*$ & $0,36 \%$ & 0,77 \\
\hline 8 & $0,01 \%$ & 0,13 & & $0,38 \%$ & 0,78 \\
\hline 9 & $-0,04 \%$ & $-0,35$ & & $0,34 \%$ & 0,68 \\
\hline 10 & $0,10 \%$ & 0,87 & & $0,43 \%$ & 0,86 \\
\hline INTERVAL (DAYS) & & CAR (\%) & & & t statistic \\
\hline-10 to -2 & & $0,8 \%$ & & & 2,26 \\
\hline-1 to 0 & & $-1,0 \%$ & & & $-6,21$ \\
\hline 1 to 10 & & $0,7 \%$ & & & 1,77 \\
\hline-10 to 10 & & $0,4 \%$ & & & 0,86 \\
\hline
\end{tabular}

* Significant at 5\% level (two-tailed test).

** Significant at $1 \%$ level (two-tailed test). 
Figure 2

Abnormal Returns and Curvilative Abnormal Retums

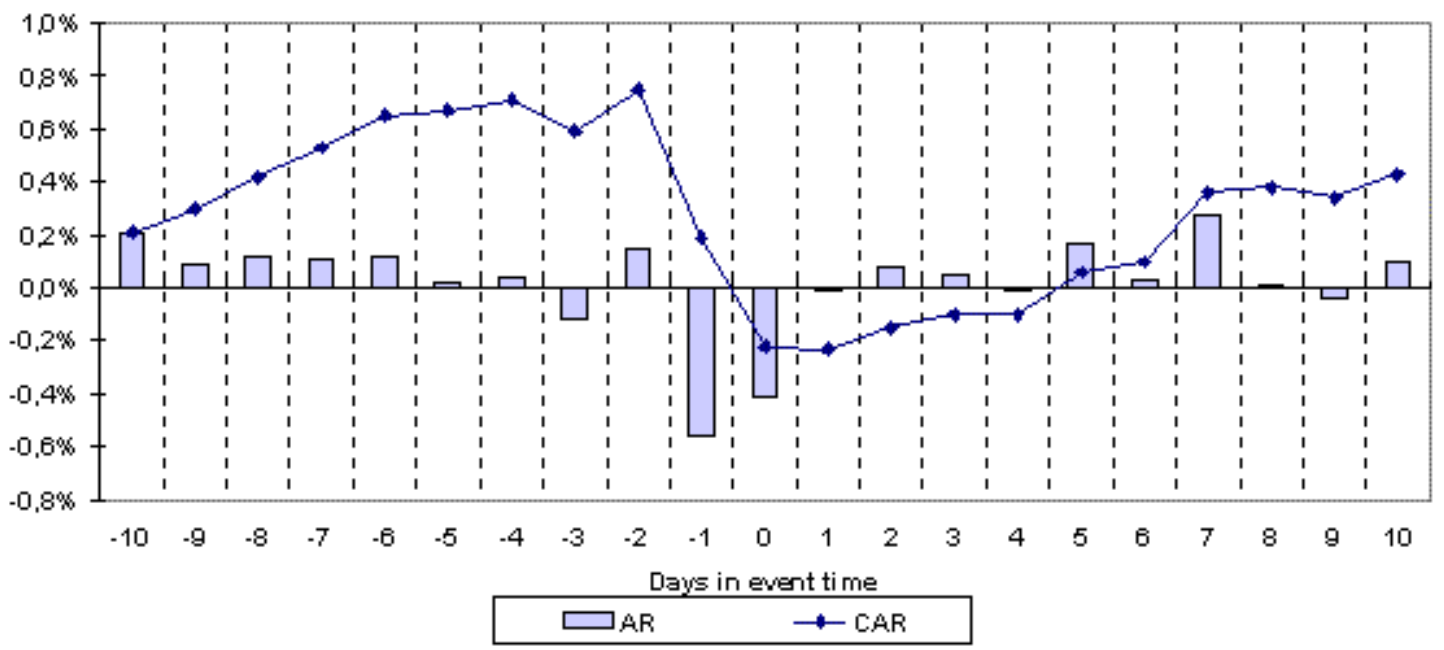

Figume 3

Cumblative Aknomal Retorn by Year of Is sue

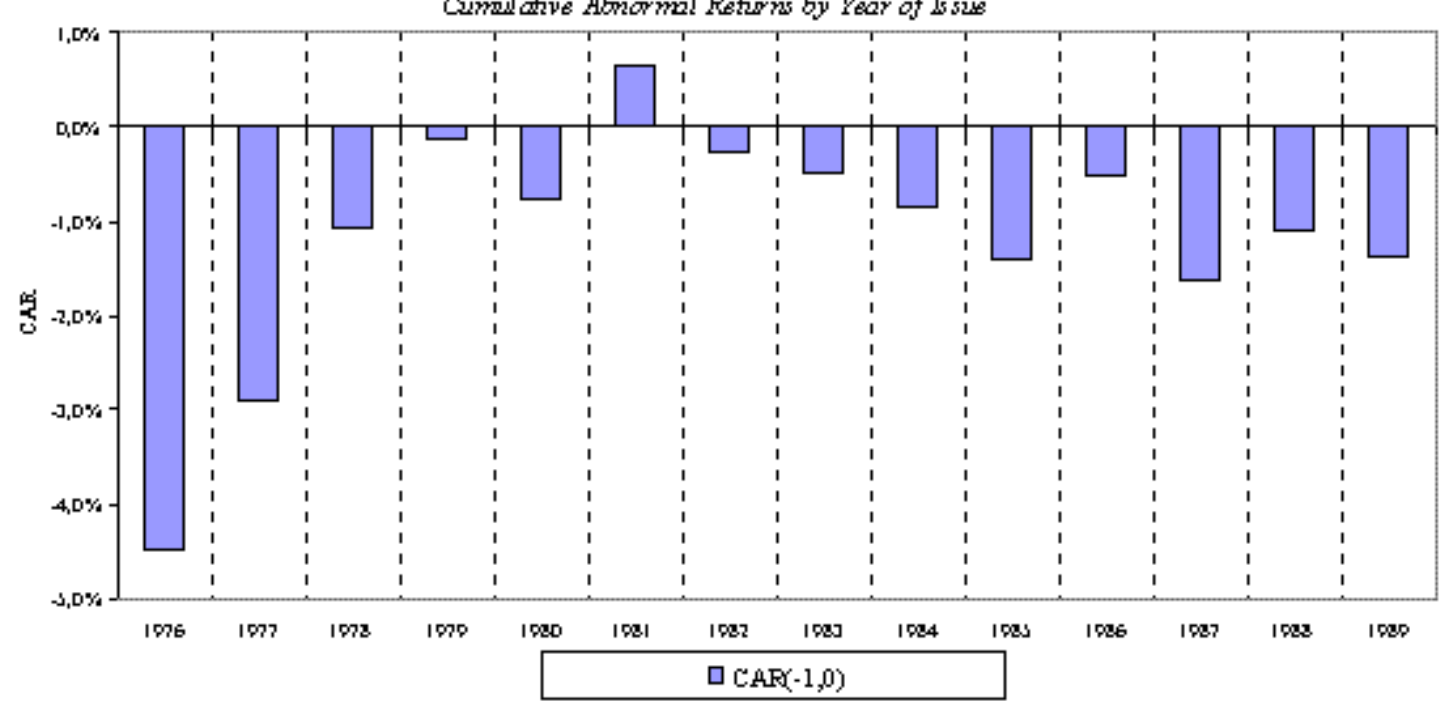




\section{B. Alternative Procedures and Results}

\section{a. CORRECTING FOR CluStering}

To this point we have assumed that abnormal returns are uncorrelated across securities which is a reasonable assumption when there is no overlapping among the event windows. The sample in this study does present some degree of overlapping of the windows, so we have to correct for clustering to check if the results change. Both (Schipper and Thompson, 1983), and (Malatesta and Thompson, 1985) propose to handle clustering by analyzing the abnormal returns on a security by security basis. Their approach has the advantage of being able to handle partial clustering, where the event dates are not exactly the same across firms, but there is some overlap among the event windows. The procedure requires calculation of the cumulative abnormal returns (CAR) and their significance $\left(\mathrm{t}_{\mathrm{CAR}}\right)$ company by company, and the computation of the average $t_{\mathrm{CAR}}$ for the companies in the sample to test the hypothesis that this average t-statistic is zero. If the hypothesis is rejected we conclude that abnormal returns do exist. When we applied this methodology, $68 \%$ of the firms in the sample presented a negative $\mathrm{CAR}_{-1,0}$, and the hypothesis of zero average $t_{\mathrm{CAR}}$ was rejected with $99 \%$ confidence.

\section{b. A Non PARAmetric Test.}

The methodology and tests for abnormal returns applied up to here were parametric. In this section I present the results of a non parametric rank test proposed by (Corrado, 1989). This rank test is well specified even when the distribution of abnormal returns is skewed. To implement the rank test we need for each security in the sample to rank the $\mathrm{L}_{32}=21$ abnormal returns in the event window from 1 to 21 . Under the null hypothesis of no abnormal returns during the event day, the expected rank for the abnormal return on that day is $\left(\mathrm{L}_{32}+1\right) / 2=11$. The tests statistic for the null hypothesis of no abnormal return on event day zero is

$$
J_{4}=\frac{1}{N} \sum_{i=1}^{N}\left(K_{i 0}-\frac{L_{32}+1}{2}\right) / S\left(L_{32}\right)
$$


with

$$
S\left(L_{32}\right)=\sqrt{\frac{1}{L_{32}} \sum_{t=T_{2}+1}^{T_{3}}\left(\frac{1}{N} \sum_{i=1}^{N}\left(K_{i t}-\frac{L_{32}+1}{2}\right)\right)^{2}}
$$

where $K_{i t}$ represents the rank of the abnormal return of security $i$ on day $t$. Tests of the null hypothesis can be implemented using the result that the asymptotic null distribution of $\mathrm{J}_{4}$ is standard normal. The values computed for $\mathrm{J}_{4}\left(\mathrm{AR}_{-1}\right)$ and $\mathrm{J}_{4}\left(\mathrm{AR}_{0}\right)$ are 2.89 and 2.18 , allowing to reject the null hypothesis of zero AR on days -1 and zero with $99 \%$ and $95 \%$ confidence respectively. The $\mathrm{J}_{4}\left(\mathrm{CAR}_{-1,0}\right)$ is 3.58 , allowing to reject the null hypothesis of zero CAR during this two days period with $99 \%$ confidence.

\section{Cross Section Analysis of Abnormal Returns}

This section concentrates in the analysis of the 2 day cumulative abnormal return $\mathrm{CAR}_{-1,0}{ }^{20}$. Table 6 reports $\mathrm{CAR}_{-1,0}$ classified by underwriter and by type of issue announced. For the total sample the announcements of convertible bonds and the announcements of debt with equity show negative and significant at the $1 \%$ level abnormal returns. The straight debt announcements show negative but not significant abnormal returns. This results are consistent with the previous empirical evidence presented on section 1 .

${ }^{20}$ Since the presence of other announcements made by the same company around the junk bond issue announcement was not considered during the sample selection process, the size of the event window considered for the analysis was reduced to two days to partially control for the possible presence of confounding events 
Table 6

Cumulative Abnormal Returns by Underwriter and Type of Debt.

\begin{tabular}{|c|c|c|c|c|c|c|c|c|c|c|}
\hline \multirow[b]{2}{*}{ Year } & \multicolumn{4}{|c|}{ Total Sample } & \multicolumn{2}{|c|}{ Drexel Burnham } & \multicolumn{3}{|c|}{ Other Underwriters } & \multirow[b]{2}{*}{$\begin{array}{r}\text { Debt and } \\
\text { Equity (DE) }\end{array}$} \\
\hline & $\begin{array}{r}\text { Straight } \\
\text { Debt (D) }\end{array}$ & $\begin{array}{l}\text { Convertible } \\
\text { Debt }(\mathrm{CO}) \\
\end{array}$ & & $\begin{array}{r}\text { Debt and } \\
\text { Equity (DE) }\end{array}$ & $\begin{array}{r}\text { Straight } \\
\text { Debt (D) }\end{array}$ & $\begin{array}{r}\text { Convertible } \\
\text { Debt }(\mathrm{CO})\end{array}$ & $\begin{array}{r}\text { Debt and } \\
\text { Equity (DE) }\end{array}$ & $\begin{array}{r}\text { Straight } \\
\text { Debt (D) }\end{array}$ & $\begin{array}{r}\text { Convertible } \\
\text { Debt }(\mathrm{CO})\end{array}$ & \\
\hline$\overline{\mathrm{CAR}(-1,0)}$ & $\begin{array}{r}-0,28 \% \\
(-1,16)\end{array}$ & $\begin{array}{r}-1,24 \% \\
(-5,42)\end{array}$ & $* *$ & $\begin{array}{l}-2,10 \% \\
(-4,53)\end{array} * *$ & $\begin{array}{c}-0,11 \% \\
(-0,29)\end{array}$ & $\begin{array}{c}-1,28 \% \\
(-2,63)\end{array} * *$ & $\begin{array}{r}-1,02 \% \\
(-1,24)\end{array}$ & $\begin{array}{c}-0,39 \% \\
(-1,25)\end{array}$ & $\begin{array}{l}-1,22 \% \\
(-4,75) * *\end{array}$ & $\begin{array}{l}-2,69 \% \\
(-4,86)\end{array} *$ \\
\hline
\end{tabular}

Tests for Differences of Means Across Subsamples

Total Sample: Significance of the Difference of AR Across Types of Issue.

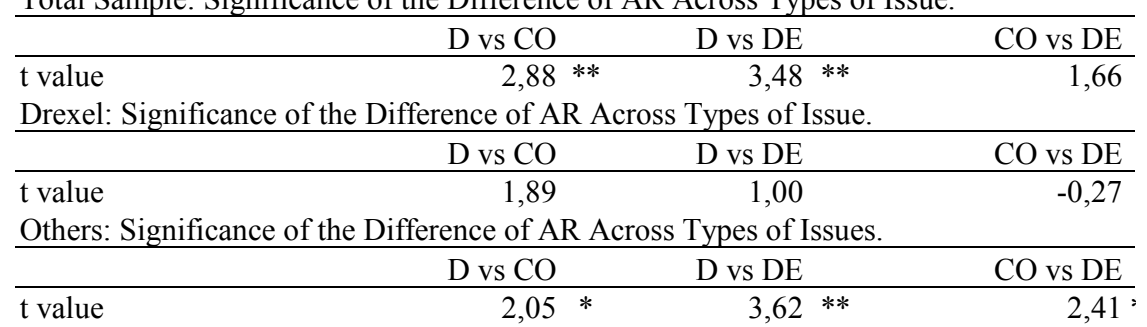

Significance of Difference of AR Between Drexel and Others

\begin{tabular}{lrrrr}
\hline & $\mathrm{D}$ & $\mathrm{CO}$ & $\mathrm{DE}$ & $\mathrm{ALL}$ \\
\hline $\mathrm{t}$ value & 0,57 & $-0,11$ & 1,68 & 3,30
\end{tabular}$* *$

CAR $(-1,0)$ represents the cumulative abnormal returns between days -1 and 0 of the event window.

* Significant at the $5 \%$ level.

** Significant at the $1 \%$ level. 
The second part of Table 6 reports the results of testing the hypotheses that the abnormal returns are all the same across different types of debt announcements ${ }^{21}$. The hypothesis that straight debt issues and convertible debt issues have the same effect in stock prices is rejected with 99\% confidence for $\mathrm{CAR}_{-1,0}$. The hypothesis that straight debt issues and issues of debt and equity have the same impact on stock prices is also rejected with $99 \%$ confidence. The hypothesis that convertible debt issues and issues of debt and equity generate the same abnormal returns can not be rejected for $\mathrm{CAR}_{-1,0}$.

From Table 6 we also observe that Drexel Burnham, when compared with the other underwriters, shows less negative abnormal returns for straight debt issues and for issues of debt and equity, but slightly more negative abnormal returns for the announcements of convertible bonds. The second part of Table 5a shows that the differences in abnormal return between Drexel and other underwriters are not significant when we control for type of issue.

The comparison of abnormal returns across underwriter and rating of the issue are reported in Table 7. For the total sample, $\mathrm{CAR}_{-1,0}$ does not show a clear tendency across ratings, and actually the hypothesis of the abnormal returns being all equal can not be rejected. When comparing Drexel Burnham with the other underwriters, the announcements underwrited by Drexel present negative abnormal returns closer to zero for all the bond ratings. The second part of Table 7 shows that those differences across underwriter are not significant when controlling for rating of the issue.

It is hard to make conclusions based on the comparison of the abnormal returns across subsamples since each of them could potentially have different characteristics that are not captured by the grouping ${ }^{22}$. In an effort to identify the factors that really explain the differences in abnormal

\footnotetext{
${ }^{21}$ Given subsamples 1 and 2 with estimated cumulative abnormal returns $\mathrm{CAR}_{1}$ and $\mathrm{CAR}_{2}$, and estimated variances for the CARs of $\sigma_{1}^{2} a n d \sigma_{2}^{2}$, the $\mathrm{t}$ statistic applied to test the hypothesis of zero difference of means across subsamples is computed as $t=\left(C A R_{1}-C A R_{2}\right) / \sqrt{\sigma_{1}^{2}+\sigma_{2}^{2}}$

${ }^{22}$ For example when comparing sub-samples across rating, they could still have a different composition in terms of the type of debt issued, size of the issuer, size of the issue, underwriter name, or year of issue. Those differences could be the ones explaining different abnormal returns for issues of bonds with different rating.
} 
returns across companies cross section regressions were run. The variable to be explained was the individual $\mathrm{CAR}_{-1,0}$, and the explanatory variables used were the size of the issuer measured as the natural log of the market value of the equity of the company (SIZE), the relative size of the issue computed as the ratio of dollar amount of the issue over market value of equity of the issuer (RELSIZE), and dummies for the rating of the issues, for the type of debt issued, for the underwriter, for the pre announcement performance, for recessions, and for the year of the announcement.

Table 8 reports the results of different cross section regressions. The only 23variables with some explanatory power are the ones representing the type of issue announcement, recessions, and the one indicating issues announced during 1976. The negative coefficients for the dummies used to identify type of issue suggest that the announcement of the issue of either debt and equity (DE) or convertible bonds (CO) has a stronger negative impact on the stock price than the announcement of the issue of straight debt. The positive coefficient for the dummy indicating recessions suggests that the announcement of junk bond issues would generate a weaker negative stock price effect during economic downturns. The negative coefficient for the dummy used to identify announcements made in 1976, indicates that the negative stock price reaction was particularly strong on the first year junk bonds started to be issued.

The positive sign for size of the issuer suggests that the asymmetry of information between investors and the managers of the company may be less serious for large firms. The positive sign for the relative size of the issue indicates that announcements have a more positive impact in stock price of bigger firms, which contradicts the predictions made by the (Miller and Rock, 1985) model. 


\section{Table 7}

Cumulatife Apnormal Returns by Underwriter and Rating

43

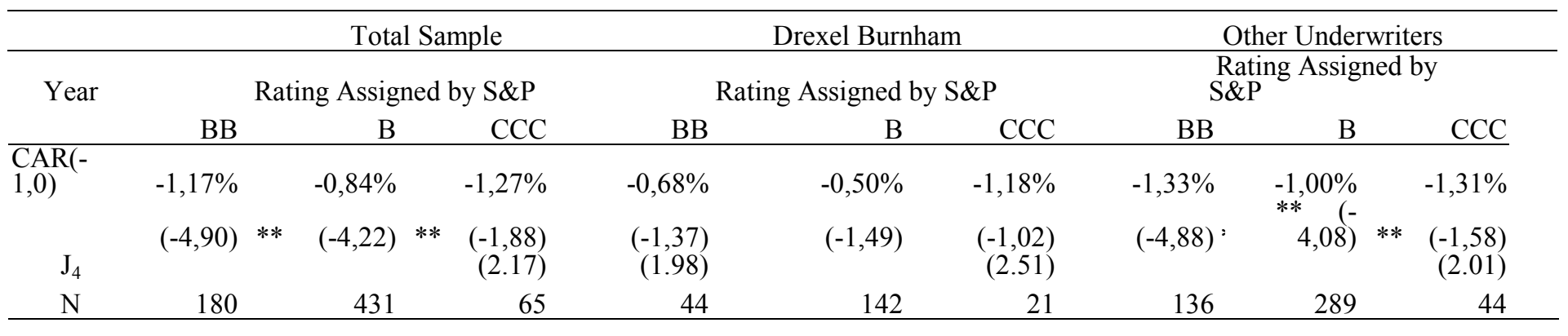

Tests for Differences of Means Across Subsamples

Total Sample: Significance of the Difference of AR Across Types of Issue.

\begin{tabular}{rrrr}
\hline & BB vs B & BB vs CCC & B vs CCC \\
\hline CAR(-1,0) & $-1,06$ & 0,14 & 0,61
\end{tabular}

Drexel: Significance of the Difference of AR Across Types of Issue.

\begin{tabular}{lrrr}
\hline & BB vs B & BB vs CCC & B vs CCC \\
\hline CAR(-1,0) & $-0,30$ & 0,40 & 0,57 \\
Others: Significance of the Difference of AR Across Types of Issues. & \\
\hline
\end{tabular}

Others: Significance of the Difference of AR Across Types of Issues.

\begin{tabular}{lrrr}
\hline CAR(-1,0) & $-0,90$ & $-0,02$ & 0,36
\end{tabular}

Significance of Difference of AR Between Drexel and Others

\begin{tabular}{lrrrr}
\hline & BB & B & CCC & ALL \\
\hline CAR(-1,0) & 1,15 & 1,20 & 0,09 & $3,43 * *$
\end{tabular}

CAR $(-1,0)$ represents the cumulative abnormal returns between days -1 and 0 of the event window. level.

* Significant at the $5 \% \quad * *$ Significant at the $1 \%$

$\mathrm{J}_{4}$ corresponds to the Corrado non parametric rank test. When applied to small subsamples shows that all of them present significant abnormal returns. 
Table 8

Cross Section Regressions for Cumulative Abnormal Returns

\begin{tabular}{|c|c|c|c|c|c|c|c|c|}
\hline Dependent Variable & $\operatorname{CAR}(-1,0)^{\mathrm{b}}$ & & $\operatorname{CAR}(-1,0)^{\mathrm{b}}$ & & $\begin{array}{r}\text { CAR(- } \\
1,0)^{\mathrm{b}}\end{array}$ & & $\begin{array}{c}\mathrm{CAR}(- \\
1,0)^{\mathrm{b}}\end{array}$ & \\
\hline Observations & $667^{\mathrm{a}}$ & & 667 & & $667^{\mathrm{a}}$ & & 667 & \\
\hline Adjusted R Square & 0,019 & & 0,017 & & 0,013 & & 0,023 & \\
\hline Test F & 5,198 & & 2,895 & & 1,950 & & 1,690 & \\
\hline Variables $^{\mathrm{c}}$ & Coefficient & $t$ Stat & Coefficient & $t$ Stat & Coefficient & $t$ Stat & Coefficient & $t$ Stat \\
\hline Intercept & $-0,00415$ & $-1,35$ & $-0,02359$ & $-1,13$ & $-0,02844$ & $-1,15$ & $-0,03794$ & $-1,46$ \\
\hline SIZE & & & 0,00150 & 1,03 & 0,00178 & 1,08 & 0,00214 & 1,20 \\
\hline RELSIZE & & & & & 0,00087 & 0,39 & 0,00199 & 0,81 \\
\hline $\mathrm{BB}$ & & & $-0,00082$ & $-0,09$ & $-0,00127$ & $-0,14$ & 0,00000 & 0,00 \\
\hline B & & & 0,00321 & 0,36 & 0,00310 & 0,34 & 0,00226 & 0,25 \\
\hline $\mathrm{CO}$ & $-0,00950$ & $-2,52 *$ & $-0,00956$ & $-2,57 *$ & $-0,00919$ & $-2,33 *$ & $-0,00931$ & $-2,29 *$ \\
\hline $\mathrm{DE}$ & $-0,01816$ & $-3,29 * *$ & $-0,01785$ & $-3,17 * *$ & $-0,01709$ & $-2,93 * *$ & $-0,01712$ & $-2,87 * *$ \\
\hline UW & 0,00397 & 1,05 & 0,00373 & 0,98 & 0,00380 & 1,00 & 0,00277 & 0,70 \\
\hline PREMAR & & & & & 0,00103 & 0,17 & 0,00077 & 0,13 \\
\hline RECES & & & & & 0,00861 & $1,96 *$ & 0,00433 & 0,55 \\
\hline Y76 & & & & & & & $-0,02649$ & $-2,43 *$ \\
\hline Y77 & & & & & & & $-0,00927$ & $-0,79$ \\
\hline Y78 & & & & & & & 0,00673 & 0,75 \\
\hline Y79 & & & & & & & 0,01773 & 1,68 \\
\hline Y80 & & & & & & & 0,00790 & 1,09 \\
\hline Y81 & & & & & & & 0,01982 & 1,37 \\
\hline Y82 & & & & & & & 0,00649 & 0,55 \\
\hline Y83 & & & & & & & 0,01009 & 1,39 \\
\hline Y84 & & & & & & & 0,00664 & 0,98 \\
\hline Y85 & & & & & & & 0,00199 & 0,25 \\
\hline Y86 & & & & & & & 0,01013 & 1,46 \\
\hline Y87 & & & & & & & $-0,00035$ & $-0,04$ \\
\hline Y88 & & & & & & & $-0,00062$ & $-0,09$ \\
\hline
\end{tabular}

a Out of the sample of 680 firms, 13 were excluded here either because they issued bonds with 2 or more ratings, or because they issued straight and convertible debt at the same time.

${ }^{b} \mathrm{CAR}(-1,0)$ represents the cumulative abnormal return between days -1 and 0 of the event window.

'SIZE corresponds to the natural log of the market value of equity of the issuer, RELSIZE corresponds to the ratio of amount of debt issued over market value of equity of the issuer. The dummy variable CO takes value 1 when Debt Issued is Convertible, DE takes value 1 when the company is issuing debt and equity, BB takes value 1 when the rating assigned to issue is $B B, B$ takes value 1 when the rating assigned to the issue is $B$, UW takes the value 1 when the underwriter is Drexel, PREMAR is the 6 month pre announcement market adjusted return, RECES takes the value 1 when the announcement is made during a recession, and Y76 to Y88 are dummies for the year of the announcement.

*Significant at $5 \%$ level (two-tailed test).

**Significant at $1 \%$ level (two-tailed test). 


\section{Summary and Conclusions}

This paper analyzes the impact of corporate junk bond offering announcements on stock prices for a sample of 680 issues of below investment grade bonds, during the 1976-1989 period. The sample shows a $0.43 \%$ cumulative abnormal return (CAR) for a 21 day event window period, and the zero CAR hypothesis cannot be rejected. The only days of the event window period with significant abnormal returns are day -1 and day 0 , and the cumulative abnormal return of this 2 day period is $-1.0 \%$, allowing to reject the zero CAR hypothesis with $99 \%$ confidence.

The CARs for the 2 day window are negative and significant for combined announcements of bonds and equity issues $\left(\mathrm{CAR}_{-1,0}\right.$ of $\left.-2.10 \%\right)$, and for announcements of convertible bonds issues ( $\mathrm{CAR}_{-1,0}$ of $-1.24 \%$ ). Announcements of issues of straight debt $\left(\mathrm{CAR}_{-1,0}\right.$ of $\left.-0.28 \%\right)$ are not significant. These results are consistent with those of (Eckbo, 1986), (Mikkelson and Partch, 1986), and (Szewczyk, 1992), who found negative and significant abnormal returns for announcements of equity issues and convertible debt, but no significant abnormal return for the announcement of straight debt.

The positive coefficient for the dummy indicating recessions suggests that the announcement of junk bond issues would generate a weaker negative stock price effect during economic downturns. This result contradicts the model and the findings of (Covitz and Harrison, 1999). The negative coefficient for the dummy used to identify announcements made in 1976 , indicates that the negative stock price reaction was particularly strong on the first year junk bonds started to be issued. This result suggests an overreaction of the market during the period when junk bond issues were something new and relatively unknown.

(Myers and Majluf, 1984) predict that the price response to security offerings depends on the sensitivity of the value of the new securities to changes in firm value. This could be interpreted as saying that larger decreases in stock price are expected to be associated with debt offerings of lower quality rating. This result is not observed when we look at issues by rating, and the rating variables are in fact not significant when used in the cross sectional regressions. These results are consistent with the results of both (Mikkelson and Partch, 1986), and (Shyam-Sunder, 1991), who found 
no statistically significant difference across announcements of issues of bonds with different ratings.

Differences in CARs are observed across subsamples formed on the basis of other variables as the name of the underwriter, and pre announcement performance, but these variables are not significant when used in cross sectional regressions. The variables representing size of the issuer and relative size of the issue exhibit a positive sign but are not significant. The positive sign for size of the issuer could be signalling that the asymmetry of information between managers and investors is less serious the bigger the company is. The positive sign for size of the issue seems to contradict the predictions made by (Miller and Rock, 1985), because in their model the greater the unanticipated amount of new financing, the more negative the impact in stock prices will be.

\section{REFERENCES}

Asquith, P., and D.W. Mullins, (1986), "Equity Issues and Offering Dilution", Journal of Financial Economics 15, 61-89.

BREnNAN, M.J., and E.S. SchwarTZ, (1978), "Corporate Income Taxes, Valuation, and the Problem of Optimal Capital Structure", Journal of Business 51, 103-114.

Brown, S., and J.B. WARner, (1980), "Measuring security Price Performance", Journal of Financial Economics 8, 205-258.

Brown, S., and J.B. WARnER, (1985), "Using Daily Stock Returns. The Case of Event Studies”, Journal of Financial Economics 14, 3-31.

CAmpBell, J., A. Lo, and C. MacKinlay, (1997), "The Econometrics of Financial Markets, Chapter 4: Event Study Analysis”, Princeton University Press.

Corrado, C., (1989), "A Nonparametric Test for Abnormal Security Price Performance in Event Studies", Journal of Financial Economics 23, 385395.

Covitz, D., and P. HARRISON, (1999), "The Timing of Debt Issuance and Rating Migration: Theory and Evidence", The Federal Reserve, Washington D.C. 
DANN, L., and W.H. MikKelson, (1984), "Convertible Debt Issuance, Capital Structure Change and Financing-Related Information: Some new Evidence", Journal of Financial Economics 13, 157-186.

De Angelo, H., and R.W. Masulis, (1980), "Optimal Capital Structure Under Corporate and Personal Taxation", Journal of Financial Economics $8,3-30$.

EсKво, B.E., (1986), "Valuation Effects of Corporate Debt Offerings", Journal of Financial Economics 15, 119-151.

Galai, D., and R.W. Masulis, (1976), "The Option Pricing Model and the Risk Factor of Stock", Journal of Financial Economics 3, 53-81.

Gilson, S.C., and J.B. WARnER, (1999), "Private Versus Public Debt: Evidence From Firms That Replace Bank Loans With Junk Bonds" Working Paper, Harvard Business School, Boston.

HEINKEL, R., (1982), “A Theory of Capital Structure Relevance Under Imperfect Information", Journal of Finance 37, 1141-1150.

HiCKMAN, W.B., (1958), "Corporate Bond Quality and Investor Experience", Princeton University Press, Princeton, NJ, and the National Bureau of Economic Research, New York.

Howe, J.T., (1988), "Junk Bonds Analysis \& Portfolio Strategies", Probus Publishing Company, Chicago, Illinois.

JAIN, P.C., (1992), "Equity Issues and Changes in Expectations of Earnings by Financial Analysts", Review of Financial Studies, Volume 5, Issue 4, 669683.

Jensen, M.C., and W. Meckling, (1976), "Theory of the Firm: Managerial Behavior, Agency Costs and Ownership Structure", Journal of Financial Economics 3, 306-360.

Kraus, A., and R. Litzenberger, (1973), “A State Preference Model of Optimal Financial Leverage", Journal of Finance 28, 911-921.

Leland, H., and D. Pyle, (1977), "Information Asymmetries, Financial Structure and Financial Intermediaries", Journal of Finance 32, 371-387.

LinN, S., and J.M. PINEGAR, (1988), "The effect of Issuing Preferred Stock on Common and Preferred Stockholder Wealth", Journal of Financial Economics 22, 155-184. 
LiNTNER, J., (1965), "The Valuation of Risky Assets and the Selection of Risky Investments in Stock Portfolios and capital Budgets", Review of Economics and Statistics 47, 13-37.

Malatesta, P., and R. Thompson, (1985), "Partially Anticipated Events: A Model of Stock Price Reactions with an Application to Corporate Acquisitions", Journal of Financial Economics 14, 237-250.

MANuel, T.A., L.D. BRooKs, and F.P. SchadLER, (1993), "Common Stock Price Effects of Security Issues Conditioned by Current Earnings and Dividend Announcements", Journal of Business, Volume 66, Issue 4, 571-593.

Masulis, R.W., and A.N. KorWAR, (1986), "Seasoned Equity Offerings: An Empirical Investigation", Journal of Financial Economics 15, 91-118.

Mikkelson, W.H., and M. PARTCH, (1986), "Valuation Effects of Security Offerings and the Issuance Process", Journal of Financial Economics 15, 31-60.

MiLleR, M.H., (1977), “Debt and Taxes”, Journal of Finance 32, 261-275.

Miller, M.H., and K. Rock, (1985), "Dividend Policy Under Asymmetric Information”, Journal of Finance 40, 1031-1051.

Modigliani, F., and M. Miller, (1958), "The Cost of Capital, Corporation Finance, and the Theory of Investment", American Economic Review 48, 261-297.

Modigliani, F., and M. Miller, (1963), "Corporate Income Taxes and The Cost of Capital: A Correction”, American Economic Review, 433-443.

MYeRS, S.C., (1977), "Determinants of Corporate Borrowing", Journal of Financial Economics 5, 147-175.

Myers, S.C., and N. MAJluf, (1984), "Corporate Financing and Investment Decisions when Firms have Information that Investors do not have", Journal of Financial Economics 13, 187-221.

Ross, S., (1976), "The Arbitrage Theory of Capital Asset Pricing”, Journal of Economic Theory 13, 341-360.

SCHIPPER, K., and A. SMITH, (1986), "A Comparison of Equity Carve-Outs and Seasoned Equity Offerings: Share Price Effects and Corporate Restructuring", Journal of Financial Economics 15, 153-186. 
SCHIPPER, K., and R. THOMPSON, (1983), "The Impact of Merger Related Regulations Using Exact Test Statistics”, Journal of Accounting Research $21,184-221$.

Sharpe, W., (1964), "Capital Asset Prices: A Theory of Market Equilibrium under Conditions of Risk", Journal of Finance 19, 425-442.

ShyAm-Sunder L., (1991), "The Stock Price Effect of Risky Versus Safe Debt", Journal of Financial and Quantitative Analysis, Volume 26, Issue 4, 549558.

SZEWCZYK, S.H., (1992), "The Intra-Industry Transfer of Information Inferred from Announcements of Corporate Security Offerings", Journal of Finance, Volume 47, Issue 5, 1935-1945. 